\title{
GCU
}

Glasgow Caledonian

University

University for the Common Good

\section{Adsorption of bisphenol A onto cationic-modified zeolite}

Wang, Hong-Yu; Zhang, H; Jiang, Jia-Qian; Ma, X.

\section{Published in:}

Desalination and Water Treatment

DOI:

10.1080/19443994.2016.1172265

Publication date:

2016

Document Version

Author accepted manuscript

Link to publication in ResearchOnline

Citation for published version (Harvard):

Wang, H-Y, Zhang, H, Jiang, J-Q \& Ma , X 2016, 'Adsorption of bisphenol A onto cationic-modified zeolite', Desalination and Water Treatment, vol. 57, no. 54, pp. 26299-26306.

https://doi.org/10.1080/19443994.2016.1172265

\section{General rights}

Copyright and moral rights for the publications made accessible in the public portal are retained by the authors and/or other copyright owners and it is a condition of accessing publications that users recognise and abide by the legal requirements associated with these rights.

Take down policy

If you believe that this document breaches copyright please view our takedown policy at https://edshare.gcu.ac.uk/id/eprint/5179 for details of how to contact us. 


\title{
Adsorption of bisphenol a onto cationic modified zeolite
}

\author{
H. Wang, ${ }^{1 \dagger}$ H. Zhang, ${ }^{1}$ Jia-Qian Jiang ${ }^{2, \dagger} \mathrm{X} . \mathrm{Ma}^{1}$ \\ ${ }^{1}$ School of Civil Engineering and Architecture, Zhejiang University of Technology, \\ Hangzhou, 310014, China \\ ${ }^{2}$ School of Engineering and Built Environment, Glasgow Caledonian University, \\ Glasgow, Scotland \\ ${ }^{\dagger}$ Corresponding authors Email: jiaqian.jiang@gcu.ac.uk; hywang@zjut.edu.cn
}

\begin{abstract}
This paper concerns with the adsorption of bisphenol-A (BPA) by modified zeolites which were prepared using an orthogonal experimental design. The preparation process was optimized by the defined conditions, i.e., that $10 \%$ of cetyltrimethyl ammonium bromide was used as the optimal modifier and processing time and temperature were $36 \mathrm{~h}$ and $25^{\circ} \mathrm{C}$, respectively. The adsorption equilibrium of BPA onto the modified zeolite fits the Freundlich isotherm with a high correlation coefficient 0.996 and was defined by a second-order rate constant $\left(\mathrm{K}_{\mathrm{v}}\right)$ of $1.07 \mathrm{~g}(\mathrm{mg} \mathrm{h})^{-1}$. Furthermore, the effects of solution chemical properties on the adsorption of BPA by modified zeolites were examined. The result reveals that the best adsorption temperature was $25^{\circ} \mathrm{C}$, and the optimal $\mathrm{pH}$ ranged from 5.0 to 10.0. In addition, the adsorption capacity of BPA increased with concentrations of $\mathrm{HCO}_{3}{ }^{-}$and decreased with increasing in concentrations of $\mathrm{NO}_{3}{ }^{-}, \mathrm{OH}^{-}$, and $\mathrm{Al}^{3+}$ in the test solution.
\end{abstract}

Keywords: Adsorption; bisphenol A; cationic modified zeolite; orthogonal experimental design; water treatment 


\section{Introduction}

Bisphenol A (BPA) has been used as one of raw materials to make polycarbonate plastic and epoxy resins, along with other applications. It is one of endocrine disrupting chemicals presenting wastewaters which can mimic living animals own hormones and may lead to negative health effects [1]. Regulatory organizations have provided guidelines of safety levels of BPA for humans, which are currently being under review as a result of new scientific discoveries [2]. A recent published study [3] investigated the number of chemicals to which pregnant women are exposed and found that $99 \%$ of the investigated were detected BPA presenting in their bodies. Therefore the research for the removal of BPA from wastewater has great significance for the human beings, other living organisms and the environment.

Adsorption [4-7], ozonation, ultraviolet light irradiation [8], catalyzed oxidation method $[9,10]$ and separation by membrane process [11] have been attempted to treat water and wastewater containing the BPA. Among them, chemical/physical adsorption is generally considered to be an effective method for quickly lowering the concentrations of organic molecules in an effluent because most adsorbents such as activated carbon generally possess large accessible internal and/or external surface areas or have specific affinity which can hold selected organic pollutants [12]. Adsorbent materials for studies mainly include: zeolite [13], montmorillonite hybrid [14], activated carbon [15], and carbon nanotubes [16]. Although activated carbon is the most commonly used adsorbent in the removal of organic compounds from liquid-phase media it presents some disadvantages [17], e.g., high capital and running costs and weak hydrophilic affinity [18] due to the presence of mineral impurities and oxygen-containing functional groups. On the other hand, important features of zeolite are that they are readily to be modified to adsorb both hydrophobic and hydrophilic pollutants and easily to be regenerated than activated carbons. Zeolite have thus been studied as an effective adsorbent for the removal of organic compounds from an aqueous solution, such as acetone and toluene vapors [19], ammonia and humic acid [20], nitrosamines [21], nicotine [22], atrazine [23] and tannic 
acid [24]. However, limited studies have been reported on the adsorption of BPA from aqueous solution by cationic modified zeolites and this is the objective of this study.

The specific objectives of this work were (a) to optimize modification conditions of zeolite using the orthogonal experimental design; (b) to compare the characteristics of selected raw and cationic modified zeolites; (c) to evaluate the applicability of common isotherm models (i.e., the Langmuir and Freundlich) and to determine the kinetics of BPA adsorption; (d) to extensively assess the effects of $\mathrm{pH}$, reactions temperature and the coions presenting in the solution on the adsorption behavior of BPA.

\section{Materials and methods}

\subsection{Materials}

The natural zeolite powder used has the particle size 150-200 $\mu \mathrm{m}$. The target adsorbate, BPA $\left[\mathrm{C}_{15} \mathrm{H}_{16} \mathrm{O}_{2}\right]$, has molecule size of $0.94 \mathrm{~nm}$. The first deprotonation of BPA starts at around $\mathrm{pH} 8.0$ with $\mathrm{pKa}_{1}=9.59$ (Equation 1$)$ and the second one starts at around pH 9.0 with $\mathrm{pKa}_{2}=11.30$ (Equation 2) [25]. In view of its high value of $\log \mathrm{K}_{\mathrm{ow}}, 3.32$ [26], the stock solution of BPA was prepared with $25 \%$ methanol solution. Two different kinds of cationic surfactants were used as modifiers, namely, cetyltrimethyl ammonium bromide $(\mathrm{CTAB})$ and cetylpyridinium bromide (CPB). All chemicals and solvents used in this study were of analytical grade.

$$
\begin{aligned}
& \mathrm{H}_{2} \mathrm{BPA} \rightarrow \mathrm{H}^{+}+\mathrm{HBPA}^{-} \\
& \mathrm{H}_{2} \mathrm{BPA} \rightarrow 2 \mathrm{H}++\mathrm{BPA}^{2-}
\end{aligned}
$$

\subsection{The preparation of modified zeolite}

The natural zeolite were firstly washed with distilled water for three times in order to remove the soluble material on its surface, and then dried in a muffle at $500{ }^{\circ} \mathrm{C}$ for $2 \mathrm{~h}$, in order to remove trace organic matter in zeolite. The dried zeolite was then grinded to 150 $\mu \mathrm{m}$ particle size. The natural zeolite after pretreatment was simply named PZ. Next $10 \mathrm{~g}$ of 
the PZ was mixed with a specified amount of modifier solution. Then the mixtures were placed in a $250 \mathrm{~mL}$ conical flask and shaken at $150 \mathrm{rpm}$ for given temperature and given time. The resulting modified zeolite then was washed with distilled water until free of $\mathrm{Cl}^{-}$ (as judged by $\mathrm{AgNO}_{3}$ ), and collected by centrifugation, dried at $110{ }^{\circ} \mathrm{C}$ for $3 \mathrm{~h}$ and grinded to $150 \mu \mathrm{m}$. The properties of the zeolite were characterized using X-ray photoelectron spectrometer (XPS), X-ray fluorescence (XRF) and Brunauer-EmmettTeller (BET) surface area measurement.

\subsection{Orthogonal experimental design}

An orthogonal experimental design $\mathrm{L}_{9}\left(3^{3}\right)$ was used to evaluate the effects of modification of zeolite such as processing time, the time of zeolite mixing with surfactants, solution temperature and the mass percentage of modifiers used. These factors were treated as the variable factors in orthogonal experimental design method. Each factor had three levels as shown in Table 1.

\section{Table 1}

The levels of each factor

\begin{tabular}{lllll}
\hline Factors & $\begin{array}{l}\text { Percentage } \\
\text { of modifier }(\%)\end{array}$ & $\begin{array}{l}\text { Processing } \\
\text { time }(\mathrm{h})\end{array}$ & $\begin{array}{l}\text { Processing } \\
\text { temperature }\left({ }^{\circ} \mathrm{C}\right)\end{array}$ \\
& $\mathrm{A}$ & $\mathrm{B}$ & $\mathrm{C}$ \\
\hline Level & 1 & 3.0 & 12 & 25 \\
Level & 2 & 6.5 & 24 & 35 \\
Level & 3 & 10.0 & 36 & 45 \\
\hline
\end{tabular}

\subsection{Batch sorption experiments}

Batch adsorption experiments were carried out to obtain the adsorption isotherms. 50 $\mathrm{mg}$ modified zeolite was weighted into $250 \mathrm{~mL}$ conical flasks and mixed with $50 \mathrm{~mL}$ of test solution at given BPA concentrations and this made the zeolite dose to be $1 \mathrm{~g} \mathrm{~L}^{-1}$. The suspension was under shaking for given time at $150 \mathrm{rpm}$ and given temperature, and 
allowed to age for $1 \mathrm{~h}$. The solution $\mathrm{pH}$ was manually adjusted (before mixing with zeolites) to the given values by $\mathrm{HCl}\left(0.1 \mathrm{~mol} \mathrm{~L}^{-1}\right)$ or $\mathrm{NaOH}\left(0.1 \mathrm{~mol} \mathrm{~L}^{-1}\right)$ solution.

\subsection{Analytical testing}

The resulting suspension solutions were centrifugated at $10000 \mathrm{rpm}$ for $10 \mathrm{~min}$, and were filtered by $0.45 \mu \mathrm{m}$ membrane filtration. BPA concentrations were measured by ultraviolet spectrophotomete at a $276 \mathrm{~nm}$ wavelength and followed up the procedures recommended by the Standard Methods [27].

\section{Results and discussion}

\subsection{Orthogonal experimental design}

The results of orthogonal experimental designs for the zeolite modification by CTAB and CPB are showed in Tables 2 and 3. As shown in Tables 2 and 3, the adsorption of BPA by CTAB modified zeolite (CTABZ) was stronger than CPB modified zeolite (CPBZ), and therefore, further studies will be focus to CTABZ only. The range analysis of orthogonal experimental designs of CTABZ was to evaluate the effects of modified conditions. The means of grade and range difference of each level are listed in Table 4. The absolute of the range difference of factor A was the largest, indicating that A was the strongest influence factor. The second stronger factor was $B$. From Table 4, the best level was $A_{3} B_{3} C_{3}$. Since the range difference of $C$ was little, considering energy conservation, level $A_{3} B_{3} C_{1}$ was determined as the defined best modification conditions for preparing CTABZ. 
Table 2

$\mathrm{L}_{9}\left(3^{3}\right)$ orthogonal array and BPA removal onto CTAB modified zeolite

\begin{tabular}{lllll}
\hline Number & A & B & C & BPA removal (\%) \\
\hline 1 & 1 & 1 & 1 & 41.31 \\
2 & 1 & 2 & 2 & 33.78 \\
3 & 1 & 3 & 3 & 44.09 \\
4 & 2 & 1 & 2 & 77.84 \\
5 & 2 & 2 & 3 & 82.53 \\
6 & 2 & 3 & 1 & 80.77 \\
7 & 3 & 1 & 3 & 89.13 \\
8 & 3 & 2 & 1 & 92.96 \\
9 & 3 & 3 & 2 & 96.00 \\
\hline
\end{tabular}

Table 3

$\mathrm{L}_{9}\left(3^{3}\right)$ orthogonal array and BPA removal onto CPB modified zeolite.

\begin{tabular}{lllll}
\hline Number & A & B & C & BPA removal (\%) \\
\hline 1 & 1 & 1 & 1 & 32.55 \\
2 & 1 & 2 & 2 & 19.58 \\
3 & 1 & 3 & 3 & 27.05 \\
4 & 2 & 1 & 2 & 65.73 \\
5 & 2 & 2 & 3 & 71.91 \\
6 & 2 & 3 & 1 & 71.75 \\
7 & 3 & 1 & 3 & 87.79 \\
8 & 3 & 2 & 1 & 87.65 \\
9 & 3 & 3 & 2 & 86.74 \\
\hline
\end{tabular}

Table 4

Range difference analysis on each level

\begin{tabular}{lllll}
\hline \multirow{2}{*}{ Factors } & \multicolumn{2}{l}{ Means to each level } & Range difference \\
\cline { 2 - 4 } & 1 & 2 & 3 & 52.97 \\
\hline A & 39.73 & 80.38 & 92.70 & 4.20 \\
B & 69.42 & 69.76 & 73.62 & 2.71 \\
C & 71.68 & 69.21 & 71.92 & \\
\hline
\end{tabular}




\subsection{Characterization of zeolite}

Chemical compositions and BET surface areas of natural zeolite (PZ) and CTAB modified zeolite (CTABZ) are summarized in Table 5. The inorganic elemental composition of PZ and CTABZ are listed in Table 6. The content of carbon and nitrogen containing groups on the surfaces of CTABZ was higher than that of PZ, reflecting that the modifier, $\mathrm{CTAB}$, which consists of $\mathrm{C}, \mathrm{H}, \mathrm{N}$ and $\mathrm{Br}$, was attached onto the surface of zeolite. Therefore, after modifying, the content of $\mathrm{Br}$ element was increase from 0 to $0.94 \%$ (Table 6), and the surface area was reduced from 16.39 to $9.78 \mathrm{~m}^{2} \mathrm{~g}^{-1}$ as shown in Table 5, since CTAB occupies a part of zeolite's surface

Table 5

Surface organic elemental composition and surface areas of PZ and CTABZ

\begin{tabular}{lllll}
\hline \multirow{2}{*}{ Adsorbents } & \multicolumn{2}{l}{ Surface elemental composition } & \multicolumn{2}{l}{$\begin{array}{l}\text { Surface area } \\
\left(\mathrm{m}^{2} \mathrm{~g}^{-1}\right)\end{array}$} \\
\cline { 2 - 4 } & $\mathrm{C}(\%)$ & $\mathrm{O}(\%)$ & $\mathrm{N}(\%)$ & 16.39 \\
\hline PZ & 10.49 & 89.51 & 0.00 & 9.78 \\
\hline CTABZ & 46.06 & 51.67 & 2.27 & 9 \\
\hline
\end{tabular}

Table 6

Inorganic elemental composition of PZ and CTABZ

\begin{tabular}{lllllllll}
\hline \multirow{2}{*}{ Adsorbents } & \multicolumn{7}{l}{ Elemental composition (\%) } \\
\cline { 2 - 8 } & $\mathrm{Si}$ & $\mathrm{Al}$ & $\mathrm{Na}$ & $\mathrm{Ca}$ & $\mathrm{K}$ & $\mathrm{Br}$ & $\mathrm{Fe}$ & $\mathrm{Mg}$ \\
\hline PZ & 35.54 & 7.58 & 2.46 & 1.77 & 1.61 & 0 & 0.58 & 0.41 \\
\hline CTABZ & 35.23 & 7.75 & 2.00 & 1.72 & 1.58 & 0.94 & 0.58 & 0.49 \\
\hline
\end{tabular}

\subsection{Adsorption kinetics and isotherms}

The process of adsorption of BPA onto CTABZ could be divided into three stages. As shown in Figure 1, the first stage was identified by a fast intake of BPA in the initial 30 minutes of the reaction (Table 7), which was followed by a second stage of a sluggish approach to equilibrium lasting approximately $210 \mathrm{~min}$, and a final stage characterized by 
a slight inversion approximately after 240 minutes of contact. Sorption data were fitted well to the pseudo second-order kinetic model described. A suitable fitness between calculated and experimental data indicated that the sorption of BPA by CTABZ follows the pseudo-second-order reaction kinetics $\left(\mathrm{R}^{2}=0.996\right)$ with a rate constant of $\left(\mathrm{K}_{\mathrm{v}}\right)$ of $1.07 \mathrm{~g}$ $\mathrm{mg}^{-1} \mathrm{~h}^{-1}$ (Table 8). The pseudo second-order kinetic model can thus be described by Equation 3, where $\mathrm{q}_{\mathrm{t}}$ is the amount adsorbed at given time.

$\mathrm{d} q_{t}=1.07\left(22.46-q_{t}\right)^{2}$

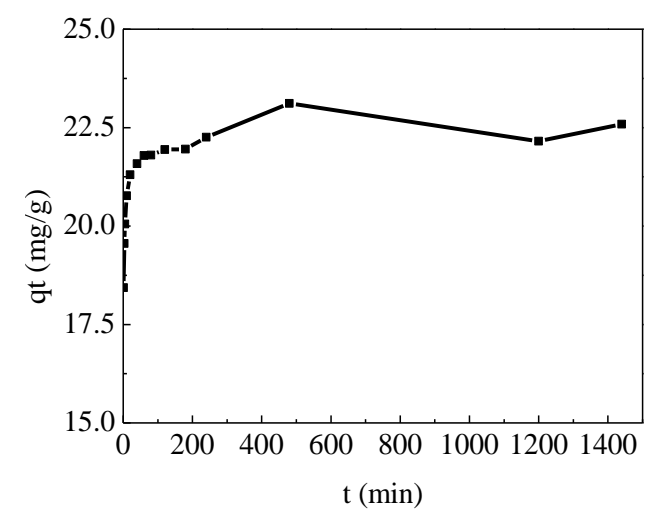

Fig. 1. Kinetics of adsorption. $50 \mathrm{~mL}$ of $50 \mathrm{mg} \mathrm{L}{ }^{-1}$ BPA solution, $100 \mathrm{mg}$ CTABZ, $\mathrm{T}=25 \quad{ }^{\circ} \mathrm{C}, \quad 150 \quad$ rpm. $\quad \mathrm{q}_{\mathrm{t}}$, adsorption capacity, $\mathrm{t}$, adsorption equilibrium time (min).

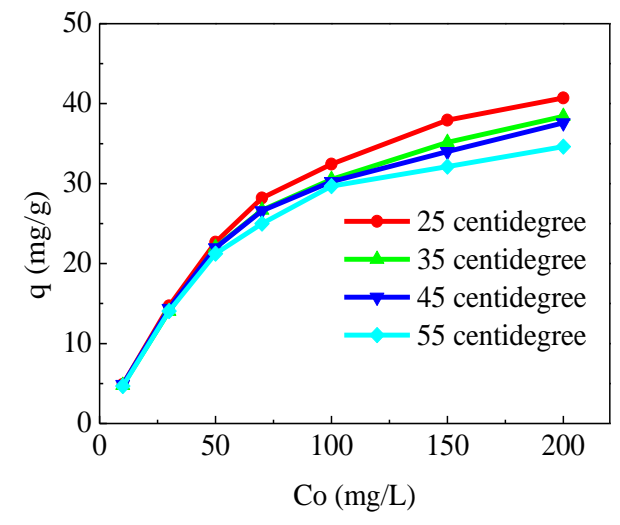

Fig. 2. The effect of BPA initial concentration and temperature on the adsorption capacity. $50 \mathrm{~mL}$ of $50 \mathrm{mg} \mathrm{L}^{-1}$ BPA solution, $100 \mathrm{mg}$ CTABZ, $150 \mathrm{rpm}$. q, adsorption capacity, $\mathrm{C}_{0}$ : initial concentration.

Equilibrium adsorptions of BPA by CTABZ were analyzed by the Langmuir and Freundlich models (Table 8). The Langmuir isotherm showed a deviation from linearity $\left(R^{2}=0.9626\right)$. The Freundlich isotherm gave a good fit $\left(R^{2}=0.9956\right)$. The Freundlich isotherm can thus be described by Equation 4 where $C_{\text {eq }}$ is the concentration of adsorbate 
at equilibrium in the liquid phase, $\mathrm{Q}_{\mathrm{m}}$ is the corresponding amount of adsorbate in the solid phase, and two coefficients, $\mathrm{K}_{\mathrm{f}}$ and $\mathrm{n}$, have been established.

$$
Q_{\mathrm{m}}=16.47 C_{e q}^{0.19}
$$

Table 7

Kinetics of adsorption between 0-30 minutes

\begin{tabular}{lllllll}
\hline $\mathrm{t}(\min )$ & 1.00 & 3.00 & 5.00 & 10.00 & 20.00 & 30.00 \\
\hline $\mathrm{q}\left(\mathrm{mg} \mathrm{g}^{-1}\right)$ & 17.81 & 19.13 & 19.62 & 19.88 & 20.73 & 21.01 \\
\hline
\end{tabular}

Table 8

Adsorption models parameters of BPA by CTABZ

\begin{tabular}{lllllllll}
\hline \multicolumn{2}{l}{ Pseudo-Second-order kinetic } & \multicolumn{3}{c}{ Langmuir isotherm } & \multicolumn{3}{c}{ Freundlich isotherm } \\
\hline $\mathrm{K}_{\mathrm{v}}$ & $\mathrm{q}_{\mathrm{e}}$ & $\mathrm{R}^{2}$ & $\begin{array}{l}\mathrm{Q}_{\mathrm{m}} \\
\left(\mathrm{mg} \mathrm{g}^{-1}\right)\end{array}$ & $\begin{array}{l}\mathrm{b} \\
\left(\mathrm{L} \mathrm{g}^{-1}\right)\end{array}$ & $\mathrm{R}^{2}$ & $\mathrm{~K}_{\mathrm{f}}$ & $1 / \mathrm{n}$ & $\mathrm{R}^{2}$ \\
$\left(\mathrm{~g} \mathrm{mg}^{-1} \mathrm{~h}^{-1}\right)$ & & & 37.85 & 0.65 & 0.963 & 16.47 & 0.19 & 0.996 \\
\hline 1.07 & 22.46 & 0.999 & 370 &
\end{tabular}

\subsection{The effect of solution chemical properties on BPA adsorption by modified zeolite}

The effects of solution chemical properties on the adsorption of BPA onto CTABZ were examined and discussed below. Batch adsorption experiments were carried $4 \mathrm{~h}$ at 150 rpm and given temperatures (e.g., $25^{\circ} \mathrm{C}$ ).

Initial BPA concentration. The sorption of BPA onto CTABZ was investigated for the initial concentrations from 50 to $200 \mathrm{mg} / \mathrm{L}$ at various temperatures as shown in Figure 2. The adsorption capacity of BPA increased from 4.88 to $40.72 \mathrm{mg} \mathrm{L}^{-1}$ with increasing the initial concentration from 50 to $200 \mathrm{mg} \mathrm{L}^{-1}$. Higher BPA initial concentration provided the power to overcome the resistance to mass transfer from water phase to solid surface [28], and also had effects on the efficiency and ability of sorption. Generally, increase in the initial concentrations would elevate the adsorption capacity until a critical initial concentration reaches when adsorbate is quickly saturated in the surface and inter layer of 
the zeolite.

Temperature. The adsorption of BPA onto CTABZ was investigated at temperature of 25, 35, 45 and $55^{\circ} \mathrm{C}$. The results of sorption isotherms were illustrated in Figure 2. The results showed that adsorption capacity of BPA at $25^{\circ} \mathrm{C}$ was the largest, and increasing in temperature slightly decreased the adsorption capacity. This can be attributed to the exothermic sorption mechanism; that the adsorption capacity of BPA by surfactantmodified zeolite and activated carbon was diminished with increasing in solution temperatures $[26,29]$. Thus, further studies were conducted at temperature of $25^{\circ} \mathrm{C}$.

Solution pH. The effect of solution $\mathrm{pH}$ on the adsorption of BPA onto CTABZ was investigated at the $\mathrm{pH}$ range from 2.0 to 11.0. Results shown in Figure 3 indicated that adsorption efficiency of BPA onto the CTABZ was good, and the adsorption capacity increased with increasing in solution $\mathrm{pH}$ ranging from 3-10. However, when solution $\mathrm{pH}$ was greater than 10.0, the adsorption capacity decreased. The phenomena can be interpreted based on the concept of first and second deprotonation equilibriums of BPA, which were occurred at $\mathrm{pH} 9.6$ and $\mathrm{pH} 11.3$, respectively. When solution $\mathrm{pH}$ was less than 10, the BPA was dissociated to form $\mathrm{H}^{+}$and BPA anions which will be easily bonded by the cationic modified CTABZ via the charge neutralisation and thus the adsorption efficiency of BPA on CTABZ increased in raising solution $\mathrm{pH}$. While $\mathrm{pH}$ was greater than 10, major compound of BPA was to be anions and this increased the solubility of BPA and thus leading to the decrease in adsorption efficiency of BPA by CTABZ. It is observed that the relative low adsorption capacity of BPA was observed when solution $\mathrm{pH}$ was less than 5 (Figure 3). Lower $\mathrm{pH}$ solutions (higher $\mathrm{H}^{+}$concentration) intend to exchange cationic ions of the modifiers combined with CTABZ and this changes CTABZ to be less hydrophobic on its surface and leads to the decrease in the reactions between BPA and CTABZ and thus adsorption efficiency. $\mathrm{pH} 10$ was determined to be the optimal $\mathrm{pH}$ to adsorb BPA by the CTABZ. 


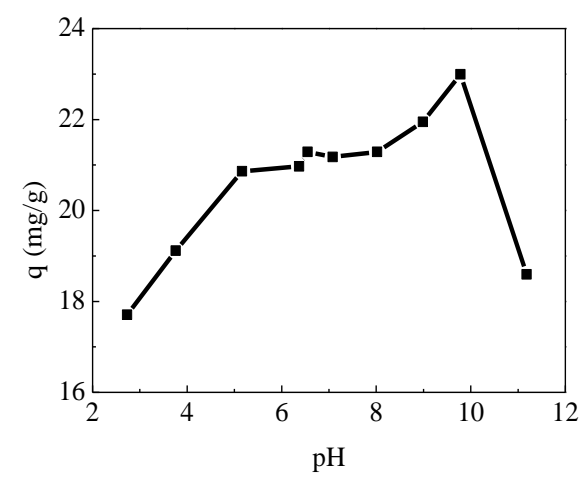

Fig. 3. The effect of $\mathrm{pH}$ on the adsorption capacity. $50 \mathrm{~mL}$ of $50 \mathrm{mg} \mathrm{L}^{-1} \mathrm{BPA}$ solution, $100 \mathrm{mg} \mathrm{CTABZ}, \mathrm{T}=25^{\circ} \mathrm{C}, 150$ rpm. $\mathrm{q}_{\mathrm{t}}$, adsorption capacity.

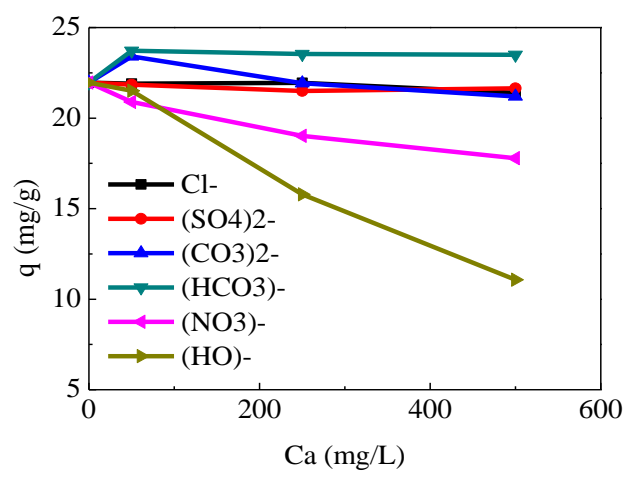

Fig. 4. The effect of anions on the adsorption capacity. $50 \mathrm{~mL}$ of $50 \mathrm{mg} \mathrm{L}^{-1}$ BPA solution, $100 \mathrm{mg}$ CTABZ, $\mathrm{T}=25^{\circ} \mathrm{C}$, $150 \mathrm{rpm}$. $\mathrm{q}_{\mathrm{t}}$, adsorption capacity, $\mathrm{C}_{\mathrm{a}}$, the concentration of anions.

The presence of anions in the test solution. The influence of representative inorganic anions on the BPA sorption by CTABZ was investigated and the results are shown in Figure 4. It can be seen that the adsorption capacity did not change in the presence of $\mathrm{CO}_{3}{ }^{2-}, \mathrm{SO}_{4}{ }^{2-}$, $\mathrm{Cl}^{-}$. However, it increased from 21.95 to $23.72 \mathrm{mg} \mathrm{L}^{-1}$ with the presence of $\mathrm{HCO}_{3}{ }^{-}$, and decreased from 21.95 to $17.78 \mathrm{mg} \mathrm{L}^{-1}$ and 21.95 to $11.07 \mathrm{mg} \mathrm{L}^{-1}$ respectively, in the presence of $\mathrm{NO}_{3}{ }^{-}$and $\mathrm{OH}^{-}$with their concentrations up to $500 \mathrm{mg} \mathrm{L}^{-1}$.

The presence of cation in solution. The influence of several inorganic cations in solution on BPA sorption by CTABZ was studied and the result is shown in Figure 5. Obviously, the presence of the monovalent $\left(\mathrm{K}^{+}, \mathrm{Na}^{+}\right)$and bivalent cations $\left(\mathrm{Ca}^{2+}, \mathrm{Mg}^{2+}\right)$ made no difference to the adsorption capacity. However, it decreased from 21.95 to $17.72 \mathrm{mg} \mathrm{L}^{-1}$ with increasing in the concentration of $\mathrm{Al}^{3+}$ up to $500 \mathrm{mg} \mathrm{L}^{-1}$. Possible reasons of this would be that solution $\mathrm{pH}$ decreased to below 10 resulting from hydrolyzing reactions of $\mathrm{Al}^{3+}$ in aqueous solutions and then adsorption capacity decreases as demonstrated in Figure 3. 


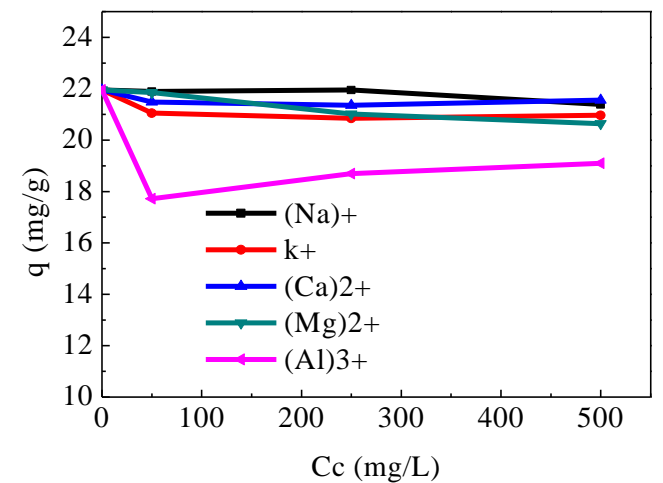

Fig. 5. The effect of cations on the adsorption capacity. $50 \mathrm{~mL}$ of $50 \mathrm{mg} \mathrm{L}^{-1} \mathrm{BPA}$ solution, $100 \mathrm{mg}$ CTABZ, $\mathrm{T}=25^{\circ} \mathrm{C}, 150 \mathrm{rpm} . \mathrm{q}_{\mathrm{t}}$, adsorption capacity, $\mathrm{C}_{\mathrm{c}}$, the concentration of cations.

\section{Conclusions}

Specific modifications of zeolite were optimized using an orthogonal experimental design and a range of analysis. The best performed modified zeolite for the removal of bisphenol-A (BPA) was prepared by $10 \%$ cetyltrimethyl ammonium bromide (CATB) with pre-treated zeolite under operating temperature $25{ }^{\circ} \mathrm{C}$ and processing time $36 \mathrm{~h}$. By comparing the property characteristics of raw zeolite (PZ) and CTAB modified zeolite (CTABZ), it is evident that the modifier, CTAB, was binded with zeolite after modification.

The results of adsorption characteristics of BPA onto CTABZ from aqueous solutions show that the sorption kinetics can be well described by a pseudo-second order reaction model with a rate constant $\left(\mathrm{K}_{\mathrm{v}}\right)$ of $1.07 \mathrm{~g} \mathrm{mg}^{-1} \mathrm{~h}^{-1}$. The BPA sorption onto the CTABZ fitted better onto the Freundlich isotherm $\left(\mathrm{R}^{2}=0.996\right)$ than the Langmuir model. Also, $25{ }^{\circ} \mathrm{C}$ was the best adsorption temperature for BPA to be adsorbed by CTABZ. Furthermore, the adsorption capacity of CTABZ increased with increasing in solution $\mathrm{pH}$, ranging from 5-10, and the optimal adsorption $\mathrm{pH}$ was $\mathrm{pH} 10$. Finally, the adsorption capacity increased when the test solution consisted of $\mathrm{HCO}_{3}{ }^{-}$but decreased when the test solution was composted of $\mathrm{NO}_{3}{ }^{-}$, $\mathrm{OH}^{-}, \mathrm{Al}^{3+}$ ions with their concentrations up to $500 \mathrm{mg} \mathrm{L}^{-1}$.

\section{References}

[1] Gore, A.C. Endocrine-Disrupting Chemicals: From Basic Research to Clinical Practice. Contemporary Endocrinology. Humana Press, New Jersey, 2007. 
[2] Ginsberg, G.; Rice, D.C. (2009) Does rapid metabolism ensure negligible risk from bisphenol A. Environ. Health Perspectives, 117: 1639-1643.

[3] Beronius, A.; Rudén, C.; Håkansson, H.; Hanberg, A. (2010) Risk to all or none? A comparative analysis of controversies in the health risk assessment of Bisphenol A. Reproductive Toxicology, 29: 132-146.

[4] Maruyama, H.; Seki, H.; Matsukawa, Y.; Suzuki, A.; Inoue, N. (2008) Adsorption behavior of bisphenol-A and diethyl phthalate onto bubblesurface. Chem. Eng. J., 41: $112-118$.

[5] Joseph, L.; Heo, J.; Park, Y.-G.; Flora, J.R.V.; Yoon, Y. (2011) Adsorption of bisphenol A and 17a-ethinyl estradiol on single walled carbon nanotubes from seawater and brackish water. Desalination, 281: 68-74.

[6] Fan, J.; Yang, W.; Li, A. (2011) Adsorption of phenol, bisphenol A and nonylphenol ethoxylates onto hypercrosslinked and aminated adsorbents. Reactive \& Functional Polymers, 71: 994-1000.

[7] Nobuyoshi, A.; Michiko, N.; Kenjiro, H.B. (2003) Synthesis of chitosan derivatives bearing cyclodextrin and adsorption of p-nonylphenol and bisphenol A. Carbohydrate Polymers, 52: 219-223.

[8] Irmak, S.; Erbatur, O.; Akgerman, A. (2005) Degradation of $17 \beta$-estradiol and bisphenol $\mathrm{A}$ in aqueous medium by using ozone and ozone/UV techniques. $\mathrm{J}$. Hazardous Materials, B126: 54-62.

[9] Coleman, H.M., Chiang, K.; Amal, R. (2005) Effects of Ag and Pt on photocatalytic degradation of endocrine disrupting chemicals in water. Chem. Eng. J., 113: 65-72.

[10] Modaressi, K.; Taylor, K.E.; Bewtra, J.K.; Biswas, N. (2005) Laccase-catalyzed removal of bisphenol-A from water: Protective effect of PEG on enzyme activity. Water Res., 39: 4309-4316.

[11] Wu, S.-H.; Dong, B.; Huang, Y. (2010) Adsorption of bisphenol A by polysulphone membrane. Desalination, 253: 22-29.

[12] Jiang, J.Q.; Ashekuzzaman, S.M. (2012) Development of novel inorganic adsorbent 
for water treatment. Current Opinion in Chem. Eng., 1(2): 191-199.

[13] Wang, H.Y.; Huang, H.F.; Jiang, J.Q. (2011) The effect of metal cations on phenol adsorption by hexadecyl-trimethyl-ammonium bromide (hdtma) modified clinoptilolite (Ct.). Separation Purif. Technol., 80(8): 658-662.

[14] Jiang, J.Q.; Zeng, Z. (2003) Comparison of modified montmorillonite adsorbents. Part II: The effects of the type of raw clays and modification conditions on the surface properties and adsorption performance of modified clays. Chemosphere, 53(1): 53-62.

[15] Nakanishi, M.; Tamai, N.; Kawasaki, T.; Nakamura,S.T. (2002) Adsorption characteristics of bisphenol A onto carbonaceous materials produced from wood chips as organic waste. J. Colloid Interface Sci., 252: 393-396.

[16] Pan, B.; Lin, D.; Mashayekhi, H.; Xing, B. (2008) Adsorption and hysteresis of bisphenol A and 17 $\alpha$-ethinyl estradiol on carbon nanomaterials. Environ. Sci. Technol., 42: $5480-5485$.

[17] Blocki, S.W. (1993) Hydrophobic zeolite adsorbent: A proven advancement in solvent separation. Environ. Progress, 12: 226-230.

[18] Yang, R.T. Gas separation by adsorption processes. Butter Worths, Boston, 1987.

[19] Lee, D.-G.; Kim, J.-H.; Lee, C.-H. (2011) Adsorption and thermal regeneration of acetone and toluene vapors in dealuminated Y-zeolite bed. Separation and Purific. Technol., 77: 312-324.

[20] Moussavi, G.; Talebi, S.; Farrokhi, M.; Sabouti, R.M. (2011) The investigation of mechanism, kinetic and isotherm of ammonia and humic acid co-adsorption onto natural zeolite. Chem. Eng. J., 171: 1159-1169.

[21] Zhou, C.F.; Zhu, J.H. (2005) Adsorption of nitrosamines in acidic solution by zeolites. Chemo., 58: 109-114.

[22] Lazarevic, N.; Adnadjevic, B.; Jovanovic, J. (2011) Adsorption of nicotine from aqueous solution onto hydrophobic zeolite type USY. Appl. Surf. Sci., 257: 80178023.

[23] Tarek, S.; Jamil, T.A.; Allah, G.; Ibrahim, H.S.; Saleh, T.S. (2011) Adsorption and 
isothermal models of atrazine by zeolite prepared from Egyptian kaolin. Solid State Sci., 13: 198-203.

[24] Lin, J.; Zhan, Y.; Zhu, Z.; Xing, Y. (2011) Adsorption of tannic acid from aqueous solution onto surfactant-modified zeolite. J. Hazardous Materials, 193: 102-111.

[25] Bautista-Toledo, M.A.; Ferro-García, J.; Rivera-Utrilla, C.; Moreno-Castilla, F.J.; Fernández, V. (2005) Bisphenol A removal from water by activated carbon: Effects of carbon characteristics and solution chemistry. Environ. Sci. Technol., 39: 6246-6250.

[26] Liu, G.; Ma, J.; Li, X.; Qin, Q. (2009) Adsorption of bisphenol A from aqueous solution onto activated carbons with different modification treatments. J. Hazardous Materials, 164: 1275-1280.

[27] Eaton, A.D.; Clesceri, L.S.; Rice, E.W. Greenberg, A.E. Standard Methods for the Examination of Water \& Wastewater, $21^{\text {st }}$ Ed., APHA, AWWA, WEF, Washington, DC, 2005.

[28] Liu, G.; Ma, J.; Li, X.; Qin, Q.; Li. G. (2008) Adsorption of bisphenol A from aqueous solution onto activated carbons, Environ. Sci., 29: 349-355.

[29] Dong, Y.; Wu, D.; Chen, X.; Lin, Y. (2010) Adsorption of bisphenol A from water by surfactant-modified zeolite. J. Colloid Interface Sci., 348: 585-590. 